\title{
Road Infrastructure and Enterprise Dynamics in Ethiopia (*)
}

\author{
Admasu Shiferaw \\ The College of William and Mary \\ Måns Söderbom \\ University of Gothenburg \\ Eyersusalem Siba \\ University of Gothenburg \\ Getnet Alemu \\ Addis Ababa University, Ethiopia \\ College of William and Mary
Department of Economics
Working Paper Number 128
}

March 2013

\footnotetext{
* The authors appreciate financial support for this project from the International Growth Centre (IGC). Shiferaw would like to thank the College of William and Mary for a summer grant and the Courant Research Centre-PEG of the University of Goettingen for hosting his research visit in the summer of 2012 where he did some work on this project. We thank participants at the annual conference of the Ethiopian Economic Association, the workshop on Firms and Labor Markets in Africa at Oxford University, and the Growth Week at London School of Economics for their comments. The usual disclaimer applies.
} 
COLLEGE OF WILLIAM AND MARY

DEPARTMENT OF ECONOMICS

WORKING PAPER \# 128

March 2013

\title{
Road Infrastructure and Enterprise Dynamics in Ethiopia
}

\begin{abstract}
This paper investigates firm level responses to a large scale public investment program on road infrastructure in Ethiopia during 1997 to 2010. Firms' location choices and average start-up size are examined by combining town level panel data on road accessibility with a panel of manufacturing firms for the period 1996 to 2009. We find econometric results showing that better road access increases a town's attractiveness for manufacturing firms. While towns with initially large number of firms continue to attract more firms, there has been a tendency toward convergence in the distribution of firms, reducing their geographic concentration. Average startup size in isolated locations is also smaller relative to firms entering well connected markets in terms of road access. We conclude that improved road infrastructure has a favorable impact on the entry patterns and structure of the manufacturing sector in Ethiopia.
\end{abstract}

Keywords: Road infrastructure, Firm Entry, Location Choice, Startup-Size, Ethiopian Manufacturing

Admasu Shiferaw

Economics Department

The College of William and Mary, Williamsburg, USA

PO Box 8795, Williamsburg, VA 23187

Email: ashiferaw@wm.edu

Måns Söderbom

Economics Department

University of Gothenburg, Sweden

Email: mans.soderbom@economics.gu.se

Eyersusalem Siba

Economics Department

University of Gothenburg, Sweden

Email: eyerusalem.siba@economics.gu.se

Getnet Alemu

College of Development Studies

Addis Ababa University, Ethiopia

Email: galemu2001@yahoo.com 


\section{Introduction}

Poor infrastructure and high transport costs are often identified as key constraints for industrial development in low-income countries (e.g. Bloom and Sachs, 1998). As noted by Collier (2000), manufacturing firms are intensive users of transport infrastructure services, so if such services are of poor quality, or high cost, manufacturing will be at a comparative disadvantage. Tybout (2000) argues that poor infrastructure is an important reason why markets for manufactured goods in low-income countries are often small and fragmented. In such an environment, firms start and stay small because they target small, localized product markets. These arguments appear to be consistent with the facts observed for Sub-Saharan Africa, where the infrastructure is under-developed, and the industrial sector is small and populated primarily by micro and small enterprises supplying local markets. Empirical evidence on the role of transport infrastructure for enterprise development in Africa remains very scarce, however. In this paper we analyse how improvements in road infrastructure have affected the rates of entry of new manufacturing firms and the firm size of new entrants in Ethiopia.

Several studies of advanced economies have documented a positive and statistically significant effect of better transport infrastructure on the average number of entrants in a locality. ${ }^{1}$ Given their low stock of infrastructural capital, the marginal returns to infrastructure investment are likely larger in developing countries relative to developed countries. However, the evidence on the role of infrastructure for enterprise performance in developing countries is quite limited, and refers almost

\footnotetext{
${ }^{1}$ Evidence from the US is provided in Smith and Florida (1994) and List (2001); Arauzo and Viladecans (2009), Holl (2004a) and Arauzo (2005) provide evidence from Spain; Cieslik (2005) and Holl (2004b) focus on Poland and Portugal, respectively. Arauzo et al. (2010) provide a recent review of the empirical studies in developed countries.
} 
entirely to emerging economies in Asia. ${ }^{2}$ Most studies related to infrastructure in Sub-Saharan Africa focus on the implications either for international trade ${ }^{3}$, or the decisions and outcomes of rural households. ${ }^{4}$ One exception is the analysis by Escribano, Guash and Pena (2010) which uses firm level data from 26 African countries to document the effects of a set of infrastructure indicators on aggregate productivity. ${ }^{5}$ Another recent interesting study focusing on Africa is that by Jedwab and Moradi (2011), which provides historical evidence that railway lines in the early 20 th century contributed to the boom in cocoa production in Ghana which in turn fuelled urbanization.

Our study is based on unusually rich data. We have collected GIS based panel data tracking the changes between 1997 and 2009 in the road accessibility of approximately 100 towns in Ethiopia. We match these data with census based panel data on Ethiopian manufacturing firms, enabling us to investigate the relationship between road infrastructure and the rates of entry, and the characteristics of new entrants, in a given locality. Crucial for our purposes is the fact that there have been considerable improvements in the road infrastructure over our sampling period. For example, data reported by Ethiopian Road Authorities (2011) indicate that, between 1997 and 2011, the road network expanded

\footnotetext{
${ }^{2}$ Binswanger and Khandker (1993) estimate the response of aggregate private investment and aggregate output in rural India using district level data on road networks. Rothenberg (2011) investigates the effect of highways on the location choice of new firms in Indonesia. Chen (1996) and Wei et al. (1998) examine the location choices of FDI firms in China and find a positive effect of infrastructure. Datta (2011) evaluates the impact of upgrading Indian highways and finds a significant reduction in the stock of intermediate inputs. Other studies focusing on infrastructure and various aspects of development in Asia include Donaldson (2010; India), Duflo et al. (2012; China), and Baum-Snow et al. (2012; China).

${ }^{3}$ Several macro studies of trade tend to underscore the severity of the infrastructural constraints in Sub-Saharan Africa; see e.g. Limão and Venables (2001), who ascribe a large part of Africa's low trade volume to its poor infrastructure; Buys, Deichmann and Wheeler (2010), whose simulation results suggest large gains in intra-regional trade among Sub-Saharan African countries would result from upgrading continental road networks; and Naude and Matthee (2007), who find that the bulk of manufactured exports in South Africa is produced within $100 \mathrm{~km}$ of ports suggesting high domestic transport costs.

${ }^{4}$ Dercon et al. (2008) show that rural households in Ethiopia with access to an all weather road to the nearest town have higher consumption expenditures; Renkow et al. (2004) find that transaction costs in rural Kenya increase with remoteness of villages constraining farmers' market participation; McPherson (1995) finds that micro and small enterprises located along the road and close to commercial centers have better chances of survival.

${ }^{5}$ Interestingly, Escribano et al. (2010) identify Ethiopia as one of the African countries where poor infrastructure is perceived by firms to be a particularly important constraint for performance.
} 
from $26,550 \mathrm{~km}$ to $53,997 \mathrm{~km}$, while the fraction of roads in good and serviceable conditions increased from $22 \%$ to $57 \%$. These developments are mainly due to a major public investment program, known as the Road Sector Development Program (RSDP), implemented in Ethiopia over the period 1997-2010 at a total cost of about USD 7.08 billion.

Ethiopia is an interesting case study not just because it is one of the largest countries in SSA but also because of its heavy dependence on road infrastructure for its freight and public transport services. There are practically no railways except for the rundown single-track connecting Addis Ababa and Djibouti. Only a few of the major rivers are navigable due to the country's mountainous terrain. Ethiopia has also been landlocked since the secession of Eritrea in 1993 and most of its international trade has since been channelled through the smaller and more expensive port of Djibouti.

Our empirical results indicate that better road access significantly increases a town's attractiveness for manufacturing firms: the empirical relationship between infrastructure improvements and entry rates is positive, statistically significant, and robust to treating the placement of roads as endogenous in the regression analysis. The results further indicate that while towns with initially large number of firms continue to attract more firms, there is an underlying tendency toward convergence in the distribution of manufacturing firms, reducing the degree of geographical concentration. The study also shows that firms entering isolated markets start with relatively smaller size as compared to entrants into well connected markets in terms of road infrastructure. Thus, our findings lend support to the widely held notion that transport infrastructure is important for enterprise development in Africa. More broadly, our results also add to the accumulating evidence on how the market structure shapes business decisions in Africa. Our findings are consistent, for example, with the argument advanced by Fafchamps and 
Söderbom (2013) that fragmented markets and high transport costs enable firms to supply local niche markets with little exposure to competitive pressure.

The paper is organized as follows. Section 2 discusses the conceptual and empirical frameworks of the analyses. Section 3 presents the policy process and the criteria for road placement in Ethiopia as well as our proxies for those criteria. Section 4 describes the panel data on road accessibility and manufacturing firms as well as some descriptive statistics. Section 5.1 addresses the first research question on firms' location choices using the total number of firms and the number of entrants. Section 5.2 answers the second research question referring to the average size of entrants. Conclusions and a policy discussion are offered in Section 6.

\section{Conceptual Framework and Empirical Approach}

The premise of our empirical analysis is that, other factors held constant, better road infrastructure reduces the firm's distribution costs, expands its output market, and reduces the costs of sourcing inputs. The resulting increase in the expected profitability incentivizes new firms to enter the market; it also incentivizes firms to operate on a larger scale. We thus hypothesize that improved road infrastructure results in a higher rate of entry of new firms into the manufacturing sector, and larger size of new entrants. ${ }^{6}$ To investigate the former mechanism, we take as our starting point a simple model linking the number of firms present in a particular market to the quality of infrastructure in the location:

\footnotetext{
${ }^{6}$ The precise mechanisms through which road networks boost profitability have been extensively discussed in the literature. Some contributions to the literature on economic geography, such as Krugman's (1991) core-periphery model, focus on agglomeration benefits. Such benefits are reinforced by reduced transport costs, since with better road connectivity firms can agglomerate in some location while supplying the rest of the market through efficient transport networks. Some contributions to the literature on urban economics, on the other hand, point out that lower transport costs may incentivize firms to locate in the periphery of the market rather than at the core in order to avoid congestion costs (Mills, 1967; Helpman, 1998). Since lower transport costs may change the relative attractiveness of established economic centers (large cities) versus peripheries, determining their effect on firms' location is an areas of active empirical research.
} 


$$
\operatorname{In}(\mathbb{N})=\beta_{1} R \mathbb{N}+X^{\prime} \alpha+u
$$

where $\ln (N)$ is the logarithm of the total number of manufacturing firms, $R N$ is a measure of the quality of the road infrastructure, $\beta_{1}$ is a slope coefficient to be estimated, $X$ is a vector of control variables, $\alpha$ is a vector of coefficients, and $u$ is an error term. If, as hypothesized, better infrastructure results in higher entry rates, other factors held constant, the slope parameter $\beta_{1}$ will be positive. Estimation of $\beta_{1}$ is complicated by the fact that the error term is potentially correlated with infrastructure. To eliminate time constant unobservable components of the error term that vary across towns, we exploit the panel dimension in our data and express the model in differences. We consider the within transformation,

$$
\ln N_{i t}-\overline{\ln N_{i}}=\beta_{1}\left(R N_{i t}-\overline{R N_{i}}\right)+\left(X_{i t}-\overline{X_{i}}\right) \alpha+u_{i t}-\overline{u_{i}}
$$

where $i$ is a town index, $t$ is a time index, and "bar" indicates average. This equation is the basis for the conventional fixed effects estimator. We also consider a first-differenced specification with a lag of the dependent variable added:

$$
\begin{aligned}
\ln N_{i t}-\ln N_{i, t-1}= & \gamma\left(\ln N_{i, t-1}-\ln N_{i, t-2}\right)+\beta_{1}\left(R N_{i t}-R N_{i, t-1}\right) \\
& +\left(X_{i t}-X_{i, t-1}\right) \alpha+u_{i t}-u_{i, t-1}
\end{aligned}
$$

Details of how the vector of control variables and, where appropriate, the instruments are specified are discussed later in the paper.

Estimates of equations (2) and (3) shed light on the relationship between net entry and the quality of infrastructure. The dependent variable in (2) and (3) clearly depends on firm exit as well as entry. In order to establish whether better infrastructure specifically triggers a larger inflow of new firms, we also model gross entry separately. In this part of the analysis our outcome variable is the number of start-ups in a town at a particular point in time, which we model as a function of location specific 
factors including road infrastructure. Reflecting the fact that the dependent variable only takes nonnegative integer values, that the proportion of zeros is large (approximately 70\%), and that there is clear over-dispersion across towns in the data (the average number of entrants per town is 3.3 and the variance is 16 ), we use a zero-inflated negative binomial estimator. This approach involves combining a binary estimator for the likelihood of non-zero versus zero firm entries per town-year, with the negative binomial for the number of (non-zero) entrants (Cameron and Trivedi, 2005). As a robustness check, we also consider a truncated negative binomial model in which only positive counts of entrants enter the estimation.

The second hypothesis that we wish to test is that better road accessibility increases the average size at which firms enter a market. Underlying this hypothesis is the idea that, if demand for manufactures is small and the existing markets are localized due to inadequate infrastructure, optimal firm size is small. As the scope of the market broadens due to better road access, entrants will thus be larger. The empirical model is as follows:

$$
\ln S_{k i t}=\beta_{1} R N_{i t}+X_{i t} \alpha+u_{i t}
$$

where $\ln \left(S_{k i t}\right)$ is $\log$ employment of start-up firm $k$ in town $i$ at time t. Since entry is a one-time event and we are looking at firm size at entry, our data is cross-sectional by nature and we are therefore unable to control for unobservables by means of a fixed effects approach. Our baseline estimator is therefore OLS applied to a specification which contains various control variables (which will be discussed later). However, we investigate the robustness of our results using a two-stage least squares approach in which data on road density in 1990 at the woreda (district) level are used to instrument road accessibility since 1999 . For this estimator to be consistent, the district level road density in 1990 may not correlate with the start-up size of firms after 1999 other than through the quality of 
infrastructure at the time of entry. This seems to us a plausible assumption (which, as is well known, is untestable).

Investigating the effects of road infrastructure on firm performance is complicated by the fact that the placement of roads is non-random and potentially econometrically endogenous. As discussed in Section 3, the road placement criteria used by the ERA include a desire to exploit economic potentials of localities or to benefit from favourable initial conditions that could maximize returns on public investment in roads. Moreover, interest groups such as business associations may use their economic clout to demand better road access. Such influential factors on road placement could also lure potential entrepreneurs to open businesses in a particular location making it difficult to isolate the impact of better road networks from the effect of road placement or factors that drive road placement. We use alternative approaches to address the endogeneity of road assignment. One approach is to proxy for the road placement criteria directly. This involves adding to the empirical specification controls for the economic potential of locations, population, initial conditions, and regional fixed effects. These control variables are motivated by what we know about the road placement criteria used by the ERA and the Ethiopian government (see Section 3). We also consider an instrumental variables approach. Exploiting the panel dimension in the data, we use internal instruments (lags) of potentially endogenous explanatory variables as instruments. For our model of the size of entrants, we do not have panel data (since entry is a one-time event) and we therefore use road density in 1990 (at the woreda level) to instrument for road accessibility after 1999. A similar identification strategy has recently been adopted by Baum-Snow et al. (2012). ${ }^{7}$

\footnotetext{
${ }^{7}$ Baum-Snow et al. (2012) examine how road and railroad networks has shaped the spatial transformation of urban regions in China, using measures of urban transport infrastructure in 1962 as instruments for more recent transport infrastructure.
} 


\section{Road Placement and Control Variables}

The Ethiopian government implemented three Road Sector Development Programs (RSDPs) during the period 1997-2010. The total cost of the RSDP during the 14 years was about US\$ 4.12 billion; the program was financed partly by various donors including the World Bank, European Union, ADB, NDF, BADEA, OFID, Governments of Japan, Germany, U.K., and Ireland. The first RSDP ran from 1997-2001 and the second one from 2002-2007. According to the Ethiopian Road Authority, the total road network expanded from $26,550 \mathrm{~km}$ in 1997 to $53,997 \mathrm{~km}$ in 2011 while the fraction of roads in good and serviceable conditions increased from $22 \%$ to $57 \%$ (ERA, 2011). Major activities of the RSDP include rehabilitation of 17 trunk roads, upgrading of 26 trunk and 32 link roads (roads that link trunk roads) and construction of 73 link roads. This is undoubtedly the largest infrastructure development program in the country's history and probably one of the largest in the region. Table 1 shows the improvements in road infrastructure as a result of the RSDP.

Before we examine the responses of manufacturing firms to improved road networks, we will highlight the process by which the government assigns road projects across the country. This is important because in order to identify the impact of better road networks on manufacturing firms, the effects of endogenous road placement must be isolated from the impact of the road networks themselves. This difficulty arises because of the expected overlap in the information set used by government to assign roads with the information set used by firms to choose factory locations.

The Ethiopian Road Authority (ERA) applies five criteria for the preliminary selection of new road projects that are proposed by regional states (Appendix A). Priority in road placement is given to areas with high economic potential and surplus food production. ERA also takes into account population 
distribution as well as regional equity in economic development. Road projects that pass the preliminary selection will go through feasibility studies allowing ERA to refine its selection of projects and the proposed budget. Once a five-year plan is approved by government, the number and type of road projects remain intact except for minor adjustments to accommodate high priority unanticipated road projects. The five-year RSDP is implemented through annual action plans. For the assignment of road upgrading projects, ERA follows slightly different criteria. More weight is given for existing roads with high traffic densities and better connectivity with other road networks, both of which are strongly correlated with economic potentials and market size.

Despite having a set of criteria for road placement, it is not clear what specific variables ERA uses to operationalize them. For instance, it is not clear how exactly economic potentials of different geographic locations are assessed or how regional inequality in economic development is evaluated. There is also lack of clarity about the process and criteria by which regional states prioritize their road projects for submission to ERA. It seems that the above mentioned criteria serve as broad guidelines rather than strict rules for road placement.

Assuming ERA adheres to its road assignment criteria, we attempt to control for these as much as our data permit in the empirical analysis. However, ERA's criteria are broadly defined making it difficult to measure them accurately. Since agriculture is the main stay of the Ethiopian economy, we proxy economic potential by the agricultural potential of a location. Agricultural potential is captured by a dummy variable indicating whether the woreda (district) in which a town is located is either food selfsufficient or food surplus. Information on food self-sufficiency is obtained from the Productive SafetyNets Program (PSNP) which has been implemented since 2005 by the Ethiopian government and a consortium of donors "... to provide transfers to the food insecure population in chronically food 
insecure woredas in a way that prevents asset depletion at the household level and creates assets at the community level" (Government of Ethiopia, 2004). Woredas participating in the PSNP are therefore considered to be of low agricultural potential. The other proxy for economic potential is the average number of manufacturing firms in a town during 1996 to 1998 . This variable captures initial conditions (including physical and institutional infrastructure) that propagate agglomeration benefits for firms. Such initial conditions would sustain the attractiveness of historical centres of manufacturing for potential entrants while serving as indicators of economic potential for road placement. The choice of the period 1996-1998 is motivated by the fact that road accessibility of towns showed practically no change until 1999 although the RSDP started in 1997 (see Section 4 for further discussion). This is partly because of the gestation period of road projects which often take at least two years, and partly because of the focus of the $1^{\text {st }}$ RSDP on rehabilitation and upgrading projects as opposed to building new roads.

Since population is one of the criteria for road placement, and because firms likely use population as a proxy for market size in choosing locations, we add to the set of control variables woreda level population in $2007 .^{8}$ Finally, we account for unobserved regional heterogeneity through region dummy variables. A regression of road networks during 1999-2009 on the above mentioned control variables (not reported here) shows that while our proxies for economic potential and population play a statistically significant role, most of the variation in road accessibility is captured by woreda and region fixed effects.

\footnotetext{
${ }^{8}$ Unfortunately we do not have access to woreda level population for other years than 2007.
} 
Notwithstanding our efforts to address the endogeneity problem, we also believe there are reasons to be somewhat optimistic that the endogeneity problem is not overly serious. As already indicated, RSDPS are rolled out by ERA at a five-year interval. However, we capture improvements in road accessibility at the town level based on annual implementations of the RSDP. Measuring road accessibility at a higher frequency than government's decision on road placement would mitigate the latter's feedback with respect to our annual measures of entrepreneurial decisions. Moreover, the manufacturing sector is relatively small in Ethiopia, accounting for approximately $5 \%$ of GDP. This suggests infrastructure investment decisions are not strongly dependent on the performance of the manufacturing sector.

\section{Data and Descriptive Statistics}

\subsection{Data}

We use accessibility analysis to construct indicators of the quality of the road networks measuring travel time and area accessible by road. The accessibility analysis relies on the 'Network Analysis' tools of GIS (Geographic Information System) such as Service Coverage and O-D (Origin-Destination) matrix. We prefer these indicators of infrastructure quality to other widely used proxies such as total spending on road projects or the stock of infrastructural capital. One advantage of our measures is that they reflect the type and quality of roads, in addition to the stock of roads. ERA's 2011 report on the 14 years of RSDP implementation provides project level data on roads that have been rehabilitated, upgraded or newly constructed between 1997 and $2010 .{ }^{9}$ Roads were also identified by their pavement type and condition such as asphalt or gravel roads to estimate improvements in travel time. Table B1 in Appendix B shows the expected speed per hour on each type of road which is used as conversion factor

\footnotetext{
${ }^{9}$ Since ERA's report doesn't contain the completion period for some of the projects, other documents were consulted for detailed information on project specific physical accomplishment and budget disbursement.
} 
for our accessibility analysis. Travel time and area accessible are calculated at the town level every other year from 1996 to 2008, and data for the remaining years are generated through linear interpolation.

\section{Service Coverage Analysis}

Improvements in travel time and distance at the town level were calculated using the expected travel speed in Table B1. GIS tools allow us to overlay road projects with the location coordinates of towns. This was done for 106 towns from the 2007 census of manufacturing firms carried out by the Ethiopian Statistical Agency (CSA). The GIS analysis uses a 60 minutes cutoff to observe the change in travel time using all roads that serve a town. Two alternative measurements emerge from this exercise. The first captures the total distance traveled during a 60 minute drive from the center of town while the second captures the total road accessible area during those 60 minutes of drive. The latter uses a buffer zone (area of influence) of $5 \mathrm{~km}$ on both sides of a road. Figure 1 compares the total area accessible during a one hour travel from Addis Ababa in 1996 and 2008.

\section{Origin-Destination Matrix}

Origin-Destination (OD) matrix is another GIS tool to determine the impact of road projects on travel time. It measures the travel time from a town in our sample (the origin) to major economic destinations in Ethiopia. Travel time could decline as a result of road projects that do not necessary pass through the town as long as they help improve its connection with major destinations. In that sense the O-D matrix is better than the service coverage analysis discussed above which captures only the impact of road projects in the vicinity of the selected nodes. The OD-matrix uses 15 regional capital cities and other urban centres as major economic destinations (see Table B2, Appendix B). The destinations relevant to 
a town are decided based on a 10 hour travel time threshold at the beginning of the study period, i.e., all destinations that take more than 10 hours in the base year (1996) are excluded.

\section{Data on Manufacturing Firms}

The town level panel data on road accessibility are matched with establishiment level panel data from Ethiopian manufacturing. These data have been collected by the Central Statistical Agency (CSA) of Ethiopia covering the period 1996-2009 through annual census of manufacturing establishments that employ at least 10 workers. The CSA updates its list of establishments annually in consultation with the federal and regional departments of trade and industry. All establishments are required by law to cooperate with the CSA's data collection efforts, so the fact that the response rate is very high is not surprising. All manufacturing activities except the arms industry are covered by this survey following the same sampling procedure. ${ }^{10}$

\subsection{Descriptive Statistics}

The extent of the improvements in road networks due to the RSDP is highlighted by Table 2. Column 1 shows the total area that can be accessed by road per hour of travel from the sample towns. This area has expanded on average by about $260 \mathrm{~km}^{2}$ over the 13 years of the RSDP. Column 2 shows substantial increase in total distance that can be travelled from a town (using all roads serving a town) in 60 minutes, i.e., allowing vehicles to travel $46 \mathrm{~km}$ further on average in 2009 as compared to 1996.

${ }^{10}$ This paper does not address the response to road accessibility of manufacturing establishments with less than 10 workers. According to the recent Survey of Small Scale Manufacturing carried out by the CSA, there were 43,338 manufacturing firms with less than 10 workers in 2007 as compared to 1339 firms in our sample with at least 10 workers. These are however very small firms with average firm size of about 2.75 persons including proprietors (1.56 persons if one considers only paid employees). Total employment in 2007 by such small firms was 138,951 of which only 32 per cent are paid jobs. The results in this paper therefore refer to formal sector firms which possibly are more responsive to road connectivity. Firms in our sample also account for about 72 percent of total paid jobs in the entire manufacturing sector in 2007 (and 45 percent of total manufacturing employment including unpaid family labor by small firms). 
Similarly, Column 3 shows that the average travel time to major economic destinations has declined by about 5 hours per annum during the sample period.

Table 2 shows very little, if any, improvement in road accessibility during the first few years of the RSDP. In fact it is only in 1999, more than halfway into the first RSDP, that noticeable changes in road accessibility began to emerge. ${ }^{11}$ It is also interesting to note that while road accessibility improved significantly after 1999 , the variation across towns increased at the same time. This is shown in Table 3 by the increase in the standard deviation and coefficient of variation of road accessibility during 19992009 (except for the OD measure) as compared to 1996-1998. This observation holds if we examine the variation over shorter sub-periods. We exploit this growing variation in road networks across towns in estimating the response of manufacturing firms.

Data from the CSA show that the total number of manufacturing firms increased from 617 in 1996 to 1713 in 2009 with annual average growth rate of about $7.8 \%$. Figure 2 shows a decline in the share of all manufacturing firms that are located the top five towns, from $77 \%$ in 1996 to $55 \%$ in $2009 .{ }^{12}$ The importance of the capital city in manufacturing has declined significantly to $42 \%$ in 2009 . Although these towns still host the majority of manufacturing firms in Ethiopia, it is quite clear that, in relative terms, most of the recent increase in the number of manufacturing firms has taken place in previously less important towns.

\footnotetext{
${ }^{11}$ This is mainly because of the fact that only a few road projects were launched at the beginning of the RSDP and partly because most of those projects were upgrading and rehabilitation of existing roads. The other reason is that road projects normally take several years to complete.

${ }^{12}$ The top five towns in 1996 in terms of number of firms were Addis Ababa (65.5\%), Dire Dawa (4.1\%), Bahir Dar (2.6), Hawassa $(2.4 \%)$ and Nazreth $(2.1 \%)$.
} 
Next we investigate how the number of firms present in a locality (town) varies with our infrastructure measures. Our goal at this point is to document simple (partial) correlations, as these provide a benchmark to which the econometric results in Section 5 can be usefully compared. To this end we regress the log of the number of firms on the quality of the infrastructure and a set of control variables at the level of the town as shown in equation (1). In order to better understand the importance of controlling for auxiliary factors determining firms' location choices, we show results varying the richness of the set of control variables. In this part of the analysis the firm and infrastructure variables are averaged over the 1999-2007 period, hence these data are cross-sectional. Table 4 presents the OLS results. In columns (1)-(4), the infrastructure variable is the area accessible from each town, while in columns (5)-(8) it is travel distance. With no control variables included (columns (1) and (5)), the infrastructure coefficients are large - close to unity - and statistically significant at the $1 \%$ level. Once we control for initial conditions, proxied by the log of the average initial number of firms present in the location between 1996 and 1998, and economic potential, the estimated coefficient on infrastructure is considerably reduced (columns $2,3,6$ and 7 ). This suggests that excluding proxies for road placement from the regression model overstates the positive association between the number of manufacturing firms in a town and its road accessibility. In columns 4 and 8 , finally, we add region fixed effects to the specification. While this does not lead to a noticeable increase in the R-squared, it does increase the size and significance of the coefficient on road accessibility compared to the results in columns $2,3,6$ and 7.

\section{Econometric Results}

\subsection{Road Infrastructure and Entry Decisions}


We now utilize the panel nature of our data. We first estimate the model using the fixed effects estimator which takes into account only within-town variation in road accessibility. Since our proxies for endogenous road placement in the above OLS estimation are time invariant, their effect on town level number of firms will not be estimated by the fixed effects model. Table 5 shows results that are qualitatively similar to OLS results in Table 4. Improved road accessibility, in terms of total area accessible and travel speed, significantly raise the number of firms in a town. The last column also shows that reducing travel time to major economic destinations attracts more firms to a town. Firms therefore seem to respond to road projects that pass through a town as well as to projects that connect the town with other commercial centres in Ethiopia.

While Table 5 controls for location specific fixed effects, some of which are correlated with road placement, it does not capture dynamic agglomeration effects emphasized in the economic geography literature. To account for the latter and to address the endogenous assignment of road projects, we use the Blundell and Bond (1998) system GMM estimator as indicated in equation (3). First differencing the equation removes the town and other location fixed effect and their correlation with road placement. Since first differencing the lagged dependent variable renders it endogenous, it will be instrumented by appropriate lags of the number of firms in a town. We also treat each road accessibility measure as endogenous and instrument the first differences by appropriate lags of their own. In both cases, we use the second, third and fourth period lags of the variables in levels to instruments the first differenced endogenous variables. For the equation in levels, we use a one period lag of the first differences of the number of firms and the respective road accessibility measure.

Table 6 presents the results from the system GMM estimator, where standard errors have been clustered at the town level. For each specification we test for the validity of the overidentifying 
restrictions using the Sargan-Hansen test. The p-values associated with this test are sufficiently high that we fail to reject the null hypothesis that the overidentifying restrictions are valid. We also report the Arellano-Bond test for first- and second-order autocorrelation in the time varying town specific differenced error term. The results indicate that the error term in the first difference equation follows an $\mathrm{AR}(1)$ process but not an $\mathrm{AR}(2)$ process, which is consistent with the hypothesis that the error term in levels is serially uncorrelated. This lends credibility to the use of lags as instruments in the system GMM estimator.

The coefficient on the lagged dependent variable is positive and statistically significant showing strong persistence in the annual number of firms in a town. The size of the coefficient ranges between 0.75 and 0.79 indicating to cumulative effects that make towns with historically larger fraction of firms (like Addis Ababa, Dire Dawa and Bahir Dar) to continue to provide agglomeration advantages. The agglomeration effect is measured with less precision in the model where road networks are proxied by travel time to major economic centres.

After controlling for time and location fixed effects, improved road access increases significantly the number of manufacturing firms in a town. A road project that increases travel distance from a town by $10 \%$ would increase the number of firms by $3.6 \%$. Similarly, a $10 \%$ increase in the area accessible per hour of travel would increase the number of firms by about $4 \%$. Travel time to major economic centres has the expected negative sign although it is not statistically significant. This effect is weaker than the OLS estimates which indicate that the attractiveness of a town for manufacturers depends primarily on road networks in its immediate vicinity.

The coefficients from the fixed effects estimator on travel distance and area accessible for one hour of 
drive from a town are very close to that of the system GMM estimator discussed above. This suggests that once the time-invariant location effects are controlled for, there is no correlation between the unobservables determining the firm's decision to invest in a town and the government's decision to assign a road project to that town. Since physical distance to major economic centres from a town is obviously a fixed effect, it is unlikely that roads assigned outside the immediate neighbourhood of a town would be endogenous to firms' decision to locate in that same town. In that sense, travel time to major economic destinations is much less susceptible to the endogeneity problem as compared to the other measures - suggesting that its coefficient from the fixed effects model is more reliable.

\section{Number of entrants}

The preceding discussion examines the change in the total number of firms in a town which combines the effects of both firm entry and survival. In this section we focus only on entrants. We consider a firm to be an entrant if it appears for the first time in the CSA census of manufacturing firms. Firms that reenter the sample after a temporary exit or slippage below the CSA cut-off point will not be considered as entrants. As indicated above, we use count data models for the analysis of the number of manufacturing start-ups. Our dependent variable is annual number of entrants in a town from 1999 to 2009. Because of the prevalence of zero entry at a given point in time, we use the zero-inflated negative binomial estimation. In addition to road infrastructure, the covariates include our proxies for ERA's road placement criteria. The results are shown in Table 7.

After controlling for initial number of firms and other indicators of economic potential, towns with better road accessibility have larger number of entrants. While the coefficients on area accessible and travel distance are positive and significant, the coefficients on travel time to major economic destination are not significant. While connectivity to economic hubs matters for other firm decisions, it 
does not seem to matter for number of start-ups. It is worth noticing that the initial number of manufacturing firms has a positive and significant effect on the number of new firms in a town. However, the coefficient is statistically significantly less than one suggesting that most start-ups since 1999 have chosen towns that previously were not important centres of manufacturing. Agricultural potential also matters; towns located in food surplus or food self-sufficient woredas attract more manufacturing start-ups than towns in food deficit woredas. We also tested our model using the alternative zero-truncated estimator excluding towns with zero entrants. The results (available on request) show that the positive impact of road accessibility on the count of entrants remains intact despite a significant reduction in the number of observation due to truncation.

\subsection{Road Infrastructure and the Size of Entrants}

We now investigate whether the road accessibility of towns increases the average size at which firms enter a market. If demand for manufactures is small and the existing markets are fragmented due to inadequate infrastructure, then firms will start small because of the confined scope of the potential market. As the scope of the market broadens due to better road access, entrants would start with larger firm size as compared to a town with poor road connectivity. Similarly, if both agglomeration effects and transport costs are high, large cities would host most of the start-ups but the average start-up size would be smaller in comparison with a situation where agglomeration effects are high but transport costs are lower.

Entry size is measured at the firm level unlike the number of entrants which is measured at the town level. Since entry is a one-time event and we are looking at firm size at entry, our data is crosssectional by nature and we use OLS to estimate equation (4). Once again, endogenous road placement is a potential problem that we have to address. To that effect the model includes proxies for economic 
potentials as in the previous section. Similarly we add time fixed effects to account for macroeconomic factors such as faster GDP growth and improved access to credit which could increase entry size across all towns. We also allow for region fixed effects that not only control for unobserved economic potentials but also for the ability to negotiate for more road projects at the federal level. Finally, we also consider results from a two-stage least squares approach to test the robustness of our findings.

Table 8 reports OLS estimates of the response of average entry size to changes in road accessibility of towns. It shows that the average size of entrants increases with the area accessible and travel distance per hour. Similarly, reduced travel time to major economic destinations significantly raises the average size of new firms in a town. This suggests that business size depends on the size of the local market, and that road accessibility tends to increase market size. The importance of market size is also corroborated by the positive and highly significant coefficient on population.

We also control for initial (1996-1998) number of firms in a town. While this leaves the preceding results unchanged, it reveals that firms entering a town with initially large number of firms start at a smaller size as compared to entrants to a less crowded market. This points to the competitive pressure in large markets which could also influence the location choice of entrants.

Entrepreneurs may also decide their start-up size based partly on the average size of incumbents in a town. o account for factors that may increase average firm size, we take relative entry size which is the ratio of entry size to mean firm size in a town where the latter excludes the entrants. We report results using entry size measured in absolute and relative terms. The results (available on request) reveals that towns with better road networks not only manage to attract relatively larger entrants but those entrants 
tend to be closer to the mean size of incumbent firms in the town. ${ }^{13}$ Previous studies from African countries show that firm exit rate declines with initial firm size just as firms in developed countries. ${ }^{14}$ In that sense, the increase in start-up size both in absolute and relative terms due to improved road networks is likely to contribute to firm survival which in turn would send a positive signal for potential entrants.

We test the robustness of our results on entry size by using a two-stage least squares approach. As discussed above, we use data on road density in 1990 (length of roads per thousand square meters) at the woreda level to instrument road accessibility since 1999. The argument is that while the Road Sector Development Program builds upon road networks that already existed in 1990, the latter should not directly affect an entrepreneur's decision on start-up size since 1999. This variable based on historical data on road density cannot instrument current road access in a model where the dependent variable is either the number entrants or the total number of firms at the town level. This is because manufacturing firms are still concentrated in major urban centers which have long been connected to Addis Ababa via trunk roads and continue to attract new firms. The two-stage least squares results are reported in Table 9. The coefficients on all the road access indicators are significant at $10 \%$ with the expected sign. In fact the size of the coefficients has increased substantially in comparison with the simple OLS estimates. The result that start-up size increases in response to better road accessibility is thus robust to estimation methods and specifications.

\section{Conclusion}

\footnotetext{
${ }^{13}$ Entry size is on average $55 \%$ of average firm size in a town. Only $11 \%$ of the observations show a ratio greater than one. Excluding these observations does not change the result.

${ }^{14}$ See Frazer (2005), Söderbom et al. (2006) and Shiferaw (2007).
} 
Ethiopia has experienced the largest boost in road infrastructure in its history since the second half of the 1990s. This paper examines the response of manufacturing firms to this public investment program in terms of location choice as well start-up size. It combines census based firm level panel data from the Ethiopian manufacturing sector and GIS based town level panel data on road accessibility. The response variables we examined include the total number of firms, the number of entrants as well as the size (in terms of number of workers) of start-ups in a town. The main challenge in trying to answer uor research questions is addressing the endogeneity of road placement. Using alternative approaches to control for this problem of unobserved effects, the paper shows that better road accessibility increases a town's desirability for manufacturing firms. Improvements in road networks also increase the average size of entrants by broadening the scope of the market they supply. Average entry size also increases in towns with initially few manufacturing firms, suggesting relatively high competitive pressure in relatively crowded markets. By increasing the accessibility of formerly isolated towns, the RSDP has started to increase both the number of firms in such towns as well as the average size of new firms. This suggests that public investment in roads not only expands the size of the manufacturing sector, it improves the distribution of manufacturers across towns. 


\section{References}

Arauzo, J. M. 2005. "Determinants of Industrial Location. An Application for Catalan Municipalities," Papers in Regional Science 84, 105-120.

Arauzo, J., D. Liviano, and M. Manjón.2010. "Empirical Studies in Industrial Location: An Assessment of their Methods and Results," Journal of Regional Science" Journal of Regional Science $50,3,685-711$

Arauzo, J. M. and Elisabet Viladecans. 2009. "Industrial Location at the Intra-metropolitan Level: The Role of Agglomeration Economies," Regional Studies, 43, 545-558.

Baum-Snow, Nathaniel, Loren Brandt, J. Vernon Henderson, Matthew A. Turner, and Qinghua Zhang (2012). "Roads, Railways and Decentralization of Chinese Cities," unpublished mimeo, Brown University.

Bloom, D. and J. Sachs. 1998. "Geography, Demography, and Economic Growth in Africa," Brookings Papers on Economic Activity 2,207-295.

Blundell, R., \& Bond, S. (1998). "Initial conditions and moment restrictions in dynamic panel data models," Journal of Econometrics 87,1, 115-143.

Buys, P., U. Deichmann, and D. Wheeler.2010. "Road Network Upgrading and Overland Trade Expansion in Sub-Saharan Africa" Journal of African Economies 19, 3, 399-432

Binswanger, P.H., and S.R.Khandker. 1993. "How infrastructure and financial institutions affect agricultural output and investment in India," Journal of Development Economics 41, 337-366. Cameron, A.C., and P. Trivedi. 2005. Microeconometrics: Methods and Applications. New York: Cambridge University Press.

Chen, C. 1996. "Regional Determinants of Foreign Direct Investment in Mainland China," Journal of Economic Studies 23, 2, 18-30. 
Cieslik, Andrzej. 2005. "Regional Characteristics and the Location of Foreign Firms within Poland," Applied Economics 37,863-874.

Collier, P. 2000. “Africa's Comparative Advantage.” In H. Jalilian, M. Tribe, and J. Weiss, eds., Industrial Development and Policy in Africa. Cheltenham, UK: Edward Elgar.

Datta, Saugato.2011. "The impact of improved highways on Indian firms" Journal of Development Economics - Articles in Progress DEVEC-01651

Dercon, S., D.O. Gilligan, J. Hoddinott, T. Woldehanna.2008. "The Impact of Agricultural Extension and Roads on Poverty and Consumption Growth in Fifteen Ethiopian Villages," IFPRI Discussion Paper No. 00840

Donaldson, Dave (2010). "Railroads of the Raj: Estimating the Impact of Transportation Infrastructure," NBER Working Paper No. 16487. National Bureau of Economic Research.

Duflo, Esther, Abhijit Banerjee, and Nancy Qian (2012). "On the Road: Access to Transportation Infrastructure and Economic Growth in China," NBER Working Paper No. 17897. National Bureau of Economic Research.

Escribano, Alvaro, J. Luis Guash, and Jorge Pena (2010). "Assessing the impact of infrastructure quality on firm productivity in Africa: Cross-country comparisons based on investment climate surveys from 1999 to 2005," World Bank Policy Research Working Paper 5191. Washington D.C: The World Bank.

Ethiopian Road Authority. 2011. "Assessment of 14 Years of Performance of Road Sector Development Program." Addis Ababa, Ethiopia .

Fafchamps, M., and M. Söderbom.2013. "Network Proximity and Business Practices in African Manufacturing," World Bank Economic Review, forthcoming 
Frazer, G. 2005. "Which Firms Die? A Look at Manufacturing Firm Exit in Ghana," Economic Development and Cultural Change 53, 3, 585-617.

Government of Ethiopia. 2004. Productive Safety Net Programme: Programme Implementation Manual. Addis Ababa: Ministry of Agriculture and Rural Development.

Helpman, E. 1998. "The Size of Regions," in Topics in Public Economics: Theoretical and Applied Analysis, ed. by D. Pines, E. Sadka, and I. Zilcha, Cambridge University Press: Cambridge, 33-54. Holl, Adelheid. 2004a. "Manufacturing Location and Impacts of Road Transport Infrastructure: Empirical Evidence from Spain," Regional Science and Urban Economics 34, 341-363. Holl, Adelheid. 2004b. "Transport Infrastructure, Agglomeration Economies, and Firm Birth. Empirical Evidence from Portugal," Journal of Regional Science 44, 693-712. Jedwab, Rémi and Alexandre Moradi. 2011. "Transportation Infrastructure and Development in Ghana," Working Paper No.2011-24, Paris School of Economics.

Krugman, P. 1991. "Increasing Returns and Economic Geography," Journal of Political Economy 99, $483-499$.

Limão, N., and A. J. Venables.2001. "Infrastructure, Geographical Disadvantage, Transport Costs, and Trade," The World Bank Economic Review, 15(3), 451-479.

List, J. 2001. "US County-Level Determinants of Inbound FDI: Evidence from a Two-Step Modified Count Data Model," International Journal of Industrial Organization 19, 953-973. McPherson, M. 1995. "The Hazards of Small Firms in Southern Africa," Journal of Development Studies 32, 1,31-54.

Mills, E. 1967 "An Aggregative Model of Resource Allocation in a Metropolitan Area," American Economic Review 57, 197-210. 
Naude, W. and M. Matthee. 2007. "The Significance of Transport Cost in Africa," Policy Brief No. 5, UNU-WIDER.

Renkow, M., D.G. Hallstrom, D.D. Karanja. 2004. "Rural infrastructure, transactions costs and market participation in Kenya," Journal of Development Economics 73, 349-367

Rothenberg, Alexander. 2011. "Transport Infrastructure and Firm Location Choice in Equilibrium:

Evidence from Indonesia's Highways" Unpublished Paper

Smith, F. D. and R. Florida. 1994. "Agglomeration and Industrial Location: An Econometric Analysis of Japanese-Affiliated Manufacturing Establishments in Automotive-Related Industries," Journal of Urban Economics 36, 23-41.

Söderbom, M., F. Teal, and A. Harding. 2006. "The Determinants of Survival among African Manufacturing Firms," Economic Development and Cultural Change 54,3, 533-556.

Shiferaw, A. 2007. "Firm Heterogeneity and Market Selection in Sub-Saharan Africa: Does it Spur Industrial Progress," Economic Development and Cultural Change 55, 2, 393-423.

Tybout, James R. 2000. "Manufacturing Firms in Developing Countries: How Well Do They Do, and Why?" Journal of Economic Literature 38, 11-44.

Wei, Y., X. Liu, D. Parker and K. Vaidya. 1998. "The Regional Distribution of Foreign Direct Investment in Chin," Regional Studies 33,9, 857-867. 
Table 1: Improvements in Road Infrastructure

\begin{tabular}{lll}
\hline Indicator & 1997 & $\mathbf{2 0 1 1}$ \\
\hline Proportion of asphalt roads in good condition & $17 \%$ & $74 \%$ \\
Proportion of gravel roads in good condition & $25 \%$ & $55 \%$ \\
Proportion of rural roads in good condition & $21 \%$ & $54 \%$ \\
Proportion of total road network in good condition & $22 \%$ & $57 \%$ \\
Road Density/ 1000 sq. km & $24.1 \mathrm{~km}$ & $49.1 \mathrm{~km}$ \\
Road Density/ 1000 Population & $0.46 \mathrm{~km}$ & $0.66 \mathrm{~km}$ \\
Proportion of area more than 5km from all weather & $79 \%$ & $61.2 \%$ \\
road & & \\
Average distance to all weather road & $21.4 \mathrm{~km}$ & $10.2 \mathrm{~km}$ \\
\hline
\end{tabular}

Source: Table 3 of ERA (2011) 
Table 2: Trends in Road Accessibility (Annual Average)

\begin{tabular}{rrrr}
\hline & $\begin{array}{r}\text { Area } \\
\text { Accessible } \\
(\mathrm{Km} 2)\end{array}$ & $\begin{array}{r}\text { Travel } \\
\text { Distance } \\
(\mathrm{Km})\end{array}$ & $\begin{array}{r}\text { Travel Time } \\
\text { to Major } \\
\text { Destinations } \\
\text { (hours) }\end{array}$ \\
\hline $\mathbf{1 9 9 6}$ & 1098.2 & 210.6 & 379.9 \\
$\mathbf{1 9 9 7}$ & 1100.9 & 210.9 & 379.8 \\
$\mathbf{1 9 9 8}$ & 1103.7 & 211.2 & 379.7 \\
$\mathbf{1 9 9 9}$ & 1108.5 & 211.8 & 378.5 \\
$\mathbf{2 0 0 0}$ & 1113.3 & 212.5 & 377.3 \\
$\mathbf{2 0 0 1}$ & 1139.7 & 216.3 & 369.4 \\
$\mathbf{2 0 0 2}$ & 1166.2 & 220.1 & 361.4 \\
$\mathbf{2 0 0 3}$ & 1181.2 & 222.3 & 359.7 \\
$\mathbf{2 0 0 4}$ & 1196.1 & 224.4 & 358.0 \\
$\mathbf{2 0 0 5}$ & 1235.3 & 230.4 & 350.9 \\
$\mathbf{2 0 0 6}$ & 1274.6 & 236.4 & 343.9 \\
$\mathbf{2 0 0 7}$ & 1317.7 & 246.4 & 334.7 \\
$\mathbf{2 0 0 8}$ & 1360.9 & 256.4 & 325.5 \\
$\mathbf{2 0 0 9}$ & 1360.9 & 256.4 & 325.5 \\
\hline
\end{tabular}

Source: Author's' computation based on ERA data

Table 3: Average Change in Road Accessibility (town level)

\begin{tabular}{|c|c|c|c|c|c|c|c|c|}
\hline & \multicolumn{3}{|c|}{ 1996-98 } & \multicolumn{3}{|c|}{ 1999-2009 } & \multicolumn{2}{|c|}{ Mean Difference } \\
\hline & Mean & $\begin{array}{l}\text { Std- } \\
\text { Deviation }\end{array}$ & $\begin{array}{l}\text { Coefficient } \\
\text { of } \\
\text { Variation }\end{array}$ & Mean & $\begin{array}{l}\text { Std- } \\
\text { Deviation }\end{array}$ & $\begin{array}{l}\text { Coefficient } \\
\text { of Variation }\end{array}$ & Difference & $\begin{array}{l}t \text {-test ( } p \text { - } \\
\text { value) }\end{array}$ \\
\hline $\mathrm{ACC}$ & 1100.9 & 497.7 & 0.4521 & 1223.1 & 631.6 & 0.5164 & 122.189 & 0.0024 \\
\hline TRVD & 210.9 & 119.3 & 0.5656 & 230.3 & 138.0 & 0.5994 & 19.4229 & 0.0297 \\
\hline TTOD & 379.8 & 110.8 & 0.2916 & 353.2 & 107.6 & 0.3046 & -26.6045 & 0.0003 \\
\hline
\end{tabular}

Source: Authors' computation

Note: ACC stands for area accessible by road from a town, TRVD stands for travel distance from a town and TTOD stands for travel time from origin to destination. 


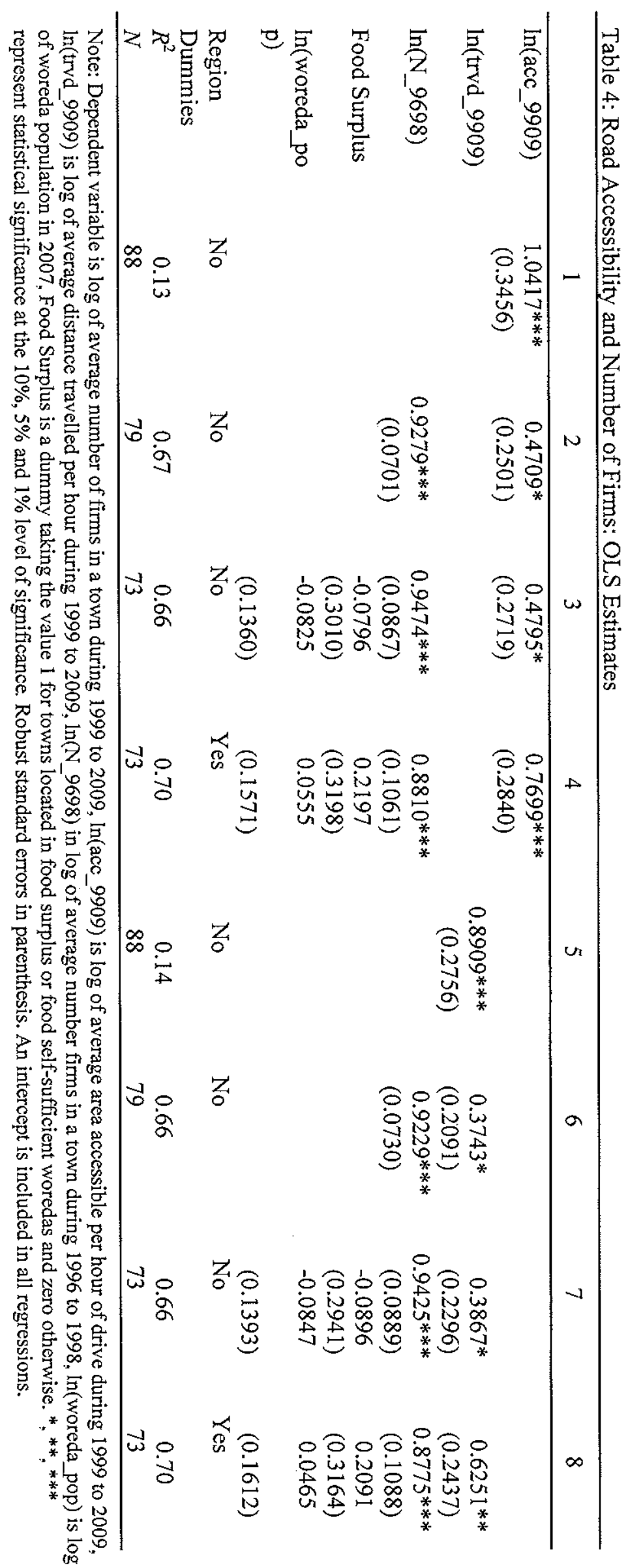


Table 5: Road Accessibility and Number of Firms: Fixed Effect Estimates

\begin{tabular}{llll}
\hline & 1 & 2 & 3 \\
\hline $\ln (\mathrm{acc})_{\text {it }}$ & $\begin{array}{l}0.3128^{* *} \\
(0.1585)\end{array}$ & & \\
$\ln (\mathrm{trvd})_{\mathrm{it}}$ & & $0.3482^{* *}$ & \\
& & $(0.1583)$ & \\
$\ln (\mathrm{ttod})_{\mathrm{it}}$ & & $-0.5350^{* * *}$ \\
& & & $(0.1875)$ \\
Year & $0.0567^{* * *}$ & $0.0566^{* * *}$ & $0.0522^{* * *}$ \\
& $(0.0040)$ & $(0.0039)$ & $(0.0043)$ \\
Observations & 1260 & 1260 & 1204 \\
Number of towns & 90 & 90 & 86 \\
R-squared & 0.23 & 0.23 & 0.23 \\
\hline
\end{tabular}

Note: Dependent variable is the total number of firms in a town, $i$ indexes town, $t$ indexes time in year, $\ln (\mathrm{acc})$ is $\log$ of area accessible, $\ln ($ trvd) is $\log$ of travel distance, and $\ln (\mathrm{ttod})$ is $\log$ of travel time to major economic destination. $*, * * * * *$ represent statistical significance at the $10 \%, 5 \%$ and $1 \%$ level of significance. Robust standard errors in parenthesis. An intercept is included in all regressions. 
Table 6: Road Accessibility and Number of Firms: System GMM Estimates

\begin{tabular}{|c|c|c|c|c|}
\hline & Travel Distance & $\begin{array}{l}\text { Area } \\
\text { Accessible }\end{array}$ & $\begin{array}{l}\text { Travel Time to } \\
\text { Major } \\
\text { Destinations }\end{array}$ & $\begin{array}{l}\text { Change in Travel } \\
\text { Time to major } \\
\text { Destin }\end{array}$ \\
\hline $\ln (N)_{i t-1}$ & $\begin{array}{l}0.7524 * * * \\
(0.0641)\end{array}$ & $\begin{array}{l}0.7490 * * * \\
(0.0702)\end{array}$ & $\begin{array}{l}0.7939^{*} \\
(0.4096)\end{array}$ & $\begin{array}{l}0.8225 * * * \\
(0.0512)\end{array}$ \\
\hline $\ln (\operatorname{trvd})_{\text {it }}$ & $\begin{array}{l}0.3559 * * \\
(0.1596)\end{array}$ & & & \\
\hline $\ln (\operatorname{acc})_{\text {it }}$ & & $\begin{array}{l}0.4076 * * \\
(0.2064)\end{array}$ & & \\
\hline $\ln (\text { ttod })_{\text {it }}$ & & & $\begin{array}{l}-0.1492 \\
(0.7765)\end{array}$ & \\
\hline$\Delta$ ttod $_{\text {it }}$ & & & & $-0.0039^{* *}(0.0018)$ \\
\hline Year Dummies & Yes & Yes & Yes & Yes \\
\hline Observations & 1170 & 1170 & 1118 & 1118 \\
\hline Number of Towns & 90 & 90 & 86 & 86 \\
\hline $\begin{array}{l}\text { Sargan statistic and p- } \\
\text { value }\end{array}$ & $81.498(0.207)$ & $82.004(0.196)$ & $77.436(0.734)$ & $76.499(0.398)$ \\
\hline AR1 & 0.000 & 0.000 & 0.000 & 0.000 \\
\hline $\mathrm{AR} 2$ & 0.405 & 0.410 & 0.374 & 0.392 \\
\hline
\end{tabular}

Note: Dependent variable is the log of total number of firms in a town, $\mathrm{i}$ indexes town, $\mathrm{t}$ indexes time in year, $\ln (\mathrm{acc})$ is $\log$ of area accessible,

$\ln ($ trvd) is $\log$ of travel distance, and $\Delta$ ttod change in travel time to major economic destination, $\ln (\mathrm{N})$ in $\log$ of total number firms in a town.

$*^{* * *}, * *$ represent statistical significance at the $10 \%, 5 \%$ and $1 \%$ level of significance, Robust standard errors in parenthesis. An intercept is included in all regressions. 
Table 7: Road Accessibility and the Number of Entrants: Zero Inflated Negative Binomial Estimation

\begin{tabular}{|c|c|c|c|}
\hline & (1) & (2) & (3) \\
\hline $\ln (\mathrm{acc})$ & $\begin{array}{l}0.4664^{*} \\
(0.2735)\end{array}$ & & \\
\hline $\ln (\operatorname{trvd})$ & & $\begin{array}{l}0.4673^{*} \\
(0.2514)\end{array}$ & \\
\hline $\ln ($ ttod $)$ & & & $\begin{array}{l}-0.2603 \\
(0.2271)\end{array}$ \\
\hline $\ln \left(N_{2} 9698\right)$ & $\begin{array}{l}0.4463 * * * \\
(0.0792)\end{array}$ & $\begin{array}{l}0.4344 * * * \\
(0.0773)\end{array}$ & $\begin{array}{l}0.4918 * * * \\
(0.0904)\end{array}$ \\
\hline Ln(woreda_pop) & $\begin{array}{l}0.0012 \\
(0.1848)\end{array}$ & $\begin{array}{l}-0.0087 \\
(0.1787)\end{array}$ & $\begin{array}{l}0.0813 \\
(0.1759)\end{array}$ \\
\hline Food Surplus & $\begin{array}{l}1.0070^{* * * *} \\
(0.3612)\end{array}$ & $\begin{array}{l}1.0395 * * * \\
(0.3384)\end{array}$ & $\begin{array}{l}1.1320 * * * \\
(0.3564)\end{array}$ \\
\hline Year Dummies & Yes & Yes & Yes \\
\hline Region Dummies & Yes & Yes & Yes \\
\hline Observations & 1019 & 1019 & 977 \\
\hline
\end{tabular}


Table 8: Road Accessibility and Size of Entrant Firms : OLS Estimates

\begin{tabular}{|c|c|c|c|c|c|c|}
\hline & 1 & 2 & 3 & 4 & 5 & 6 \\
\hline $\ln ($ acc) & $\begin{array}{l}0.2362 * * * \\
(0.0742)\end{array}$ & $\begin{array}{l}0.1969^{* *} \\
(0.0784)\end{array}$ & & & & \\
\hline $\ln (\operatorname{trvd})$ & & & $\begin{array}{l}0.1965 * * * \\
(0.0757)\end{array}$ & $\begin{array}{l}0.2032 * * \\
(0.0805)\end{array}$ & & \\
\hline $\ln ($ ttod) & & & & & $\begin{array}{l}-0.2169^{*} \\
(0.1211)\end{array}$ & $\begin{array}{l}-0.0978 \\
(0.1206)\end{array}$ \\
\hline $\ln \left(\mathrm{N} \_9698\right)$ & & $\begin{array}{l}-0.0539^{*} \\
(0.0309)\end{array}$ & & $\begin{array}{l}-0.0531 * \\
(0.0307)\end{array}$ & & $\begin{array}{l}-0.0567^{*} \\
(0.0322)\end{array}$ \\
\hline $\ln$ (woreda pop) & $\begin{array}{l}0.1014^{* * *} \\
(0.0278)\end{array}$ & $\begin{array}{l}0.1762 * * * \\
(0.0514)\end{array}$ & $\begin{array}{l}0.1040^{* * *} \\
(0.0281)\end{array}$ & $\begin{array}{l}0.1738^{* * *} \\
(0.0514)\end{array}$ & $\begin{array}{l}0.1314^{* * *} \\
(0.0281)\end{array}$ & $\begin{array}{l}0.2025 * * * \\
(0.0499)\end{array}$ \\
\hline Food Surplus & $\begin{array}{l}-0.2764^{* *} \\
(0.1240)\end{array}$ & $\begin{array}{l}-0.1351 \\
(0.1201)\end{array}$ & $\begin{array}{l}-0.2489^{* *} \\
(0.1248)\end{array}$ & $\begin{array}{l}-0.1083 \\
(0.1191)\end{array}$ & $\begin{array}{l}-0.2457^{* *} \\
(0.1242)\end{array}$ & $\begin{array}{l}-0.1015 \\
(0.1191)\end{array}$ \\
\hline Year Dummy & Yes & Yes & Yes & Yes & Yes & Yes \\
\hline Region Dummy & Yes & Yes & Yes & Yes & Yes & Yes \\
\hline Constant & $\begin{array}{l}-0.9785^{* *} \\
(0.4547)\end{array}$ & $\begin{array}{l}0.2330 \\
(0.6070)\end{array}$ & $\begin{array}{l}-0.4478 \\
(0.3633)\end{array}$ & $\begin{array}{l}0.5772 \\
(0.5417)\end{array}$ & $\begin{array}{l}3.3605^{* * *} \\
(0.7548)\end{array}$ & $\begin{array}{l}-0.1656 \\
(0.9808)\end{array}$ \\
\hline Observations & 1943 & 1560 & 1943 & 1560 & 1910 & 1530 \\
\hline R-squared & 0.05 & 0.06 & 0.05 & 0.06 & 0.05 & 0.06 \\
\hline
\end{tabular}


Table 9: Road Accessibility and Average Size of Entrant Firms: 2SLS Estimates

\begin{tabular}{llll} 
& 1 & 2 & 3 \\
\hline $\ln ($ acc) & $0.3619^{*}$ & & \\
$\ln ($ trvd) & $(0.1965)$ & $0.4022^{*}$ & \\
& & $(0.2238)$ & \\
$\ln ($ ttod) & & & $-1.0849^{*}$ \\
& & & $(0.5687)$ \\
$\ln ($ N_9698) & & -0.0392 & 0.0144 \\
& -0.0440 & $(0.0332)$ & $(0.0527)$ \\
$\ln ($ woreda_pop) & $(0.0323)$ & $0.1387^{* *}$ & $0.1458^{* *}$ \\
& $0.1498^{* *}$ & $(0.0642)$ & $(0.0635)$ \\
Food Surplus & $(0.0598)$ & -0.1346 & -0.1297 \\
& -0.1723 & $(0.1189)$ & $(0.1181)$ \\
Year Dummy & $(0.1247)$ & Yes & Yes \\
Region Dummy & Yes & Yes & Yes \\
Constant & Yes & $-1.5093^{* *}$ & $6.4142^{*}$ \\
& $-2.1228^{* *}$ & $(0.6015)$ & $(3.8764)$ \\
Observations & $(0.8359)$ & 1474 & 1474 \\
R-Squared & 1474 & 0.056 & 0.000 \\
\hline
\end{tabular}

Note: Dependent variable is the log of entry size in terms of number of workers. The instrumental variable is the woreda level road density per $1000 \mathrm{sq} . \mathrm{km}$ in $1990 . *, * * * * *$ represent statistical significance at the $10 \%, 5 \%$ and $1 \%$ level of significance. Robust standard errors in parentheses. An intercept is included in all regressions. 


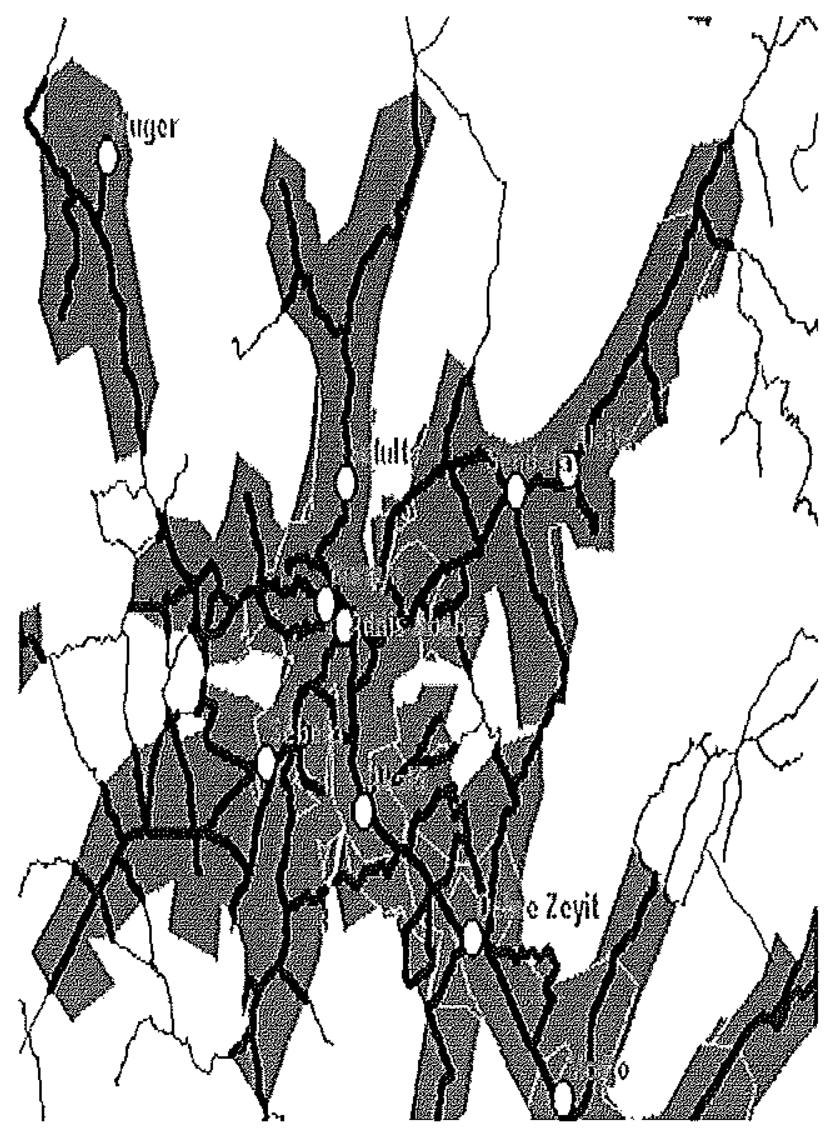

Figure 1a: Area accessible during a 1hr Drive from Addis Ababa in 1996

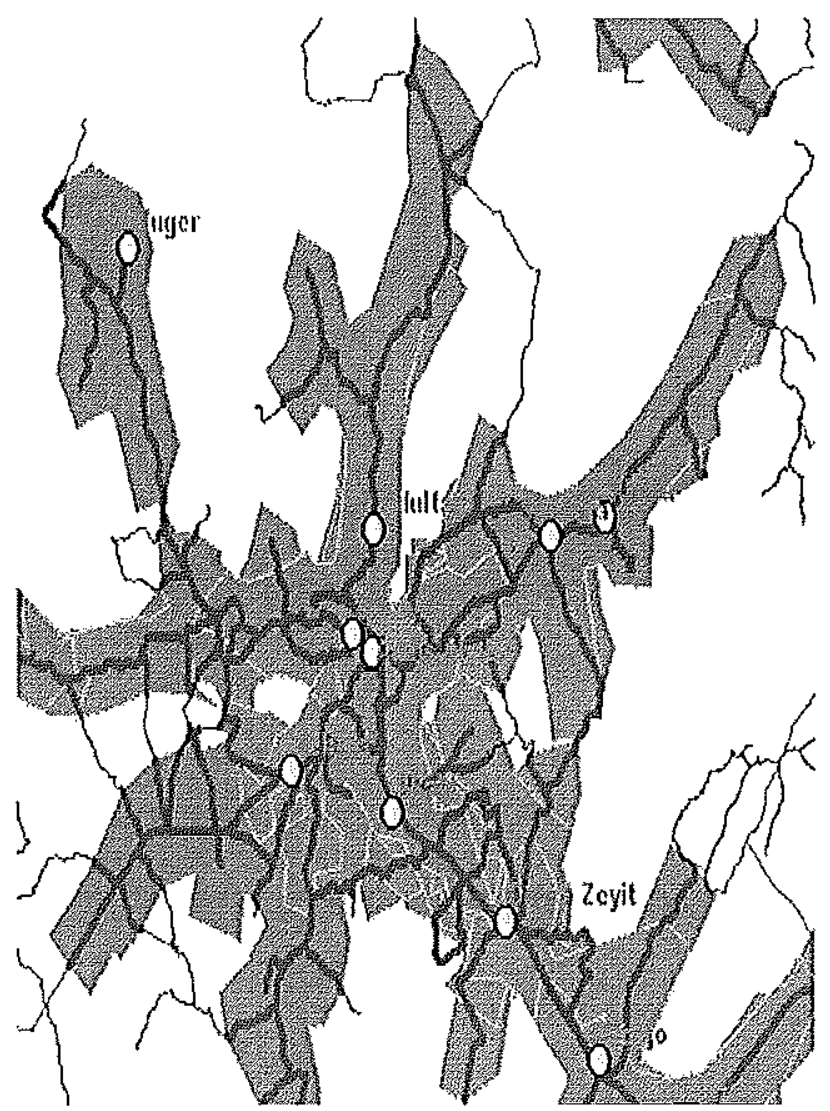

Figure 1b: Area accessible during a 1hr Drive from Addis Ababa in 2008 


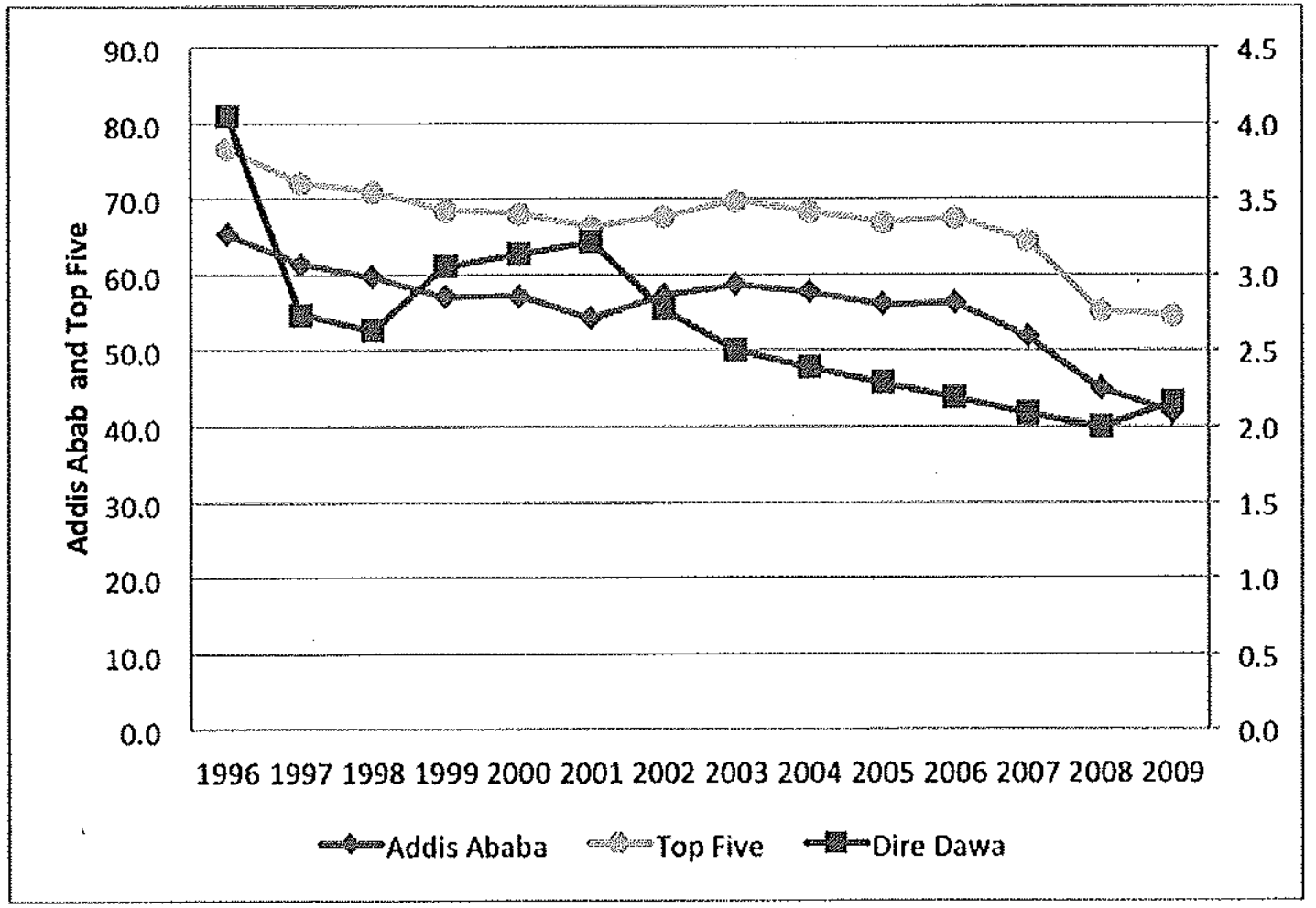

Figure 2: The Share of the Top Five Towns in Manufacturing Firms 
Appendix A: Road Assignment Process

The Ethiopian Road Authority uses the following five criteria during the preliminary selection of new road projects.

i) Roads providing access to areas with economic development potential (20\%)

ii) Roads leading to areas with surplus food and cash crop production (20\%)

iii) Roads that link existing major roads (20\%)

iv) Roads providing access to large and isolated population centers (30\%)

v) Roads that bring balanced development amongst the regions in the country and that provide access to emerging regions $(10 \%)$

This shows that economic potentials account for about $40 \%$ of the weights for new road placement while another $40 \%$ weight is given primarily to social equity concerns (criteria iv and $v$ ) that could redress existing inequality in road accessibility. ERA uses different inputs to determine the weight for each criterion. The planning department of ERA undertakes the socalled Transport Poverty Observatory on a regular basis which include "corridor analysis" and "network studies". Weights for the above mentioned criteria are determined by a committee on the basis of these studies and additional information provides by regional states and government ministries.

Proposals for new roads come mainly from regional states. Each regional state submits its proposal to ERA with its own prioritization and justification. Some government ministries also put forward proposals for new roads. For instance, the Federal Ministry of Mines and Energy requested for a new road following the discovery of potash in Dallol area. ERA evaluates all the proposals against the five selection criteria. The next step is to see how many new roads can be funded given the budget envelop. By aligning road projects with the budget envelop, ERA will present the proposal to the Federal Ministry of Construction and Urban Development. The approved proposal will be presented to the Prime Minister as well as other relevant ministries. Such meetings involve the Governor of National Bank of Ethiopia and the Federal Ministry of Finance and Economic Development (MoFED) administers the federal budget). At this level the overall framework/criteria and fund will be approved. Specific roads are to be selected by ERA based on the agreed framework. 
Following the above mentioned preliminary selection process, all selected roads will go through a feasibility study based on which a final project selection will be made. The estimated budget at preliminary level will be adjusted after the feasibility studies. The final budget is determined when the road design is completed by engineers. Once this is done the budget will be submitted to the Ministry of Finance and Economic Development (MoFED). Because of the priority given to the road sector, MoFED often approves the budget with only minor adjustments. For instance for the 2011/12 fiscal year ERA asked for Birr 17 billion and got Birr 15.4 billion.

Upgrading projects also go through a similar process. Most of the proposals for road upgrading come from regional states. The preliminary selection and prioritization of road upgrading projects by ERA is slightly different from that of new roads. The criteria and their respective weights are as follows:

i) Roads with high traffic density $-30 \%$

ii) Roads with better network connectivity $-20 \%$

iii) Roads that are in poor condition - $20 \%$

iv) Roads that link import/export and regional integration corridors - $20 \%$

v) Roads connecting investment routs (potential areas) - $10 \%$

The reason why roads with high traffic are given priority for upgrading is that traffic flows that go beyond the designed capacity could cause severe damage to the road at which level routine maintenance may not be economical.

Despite having a set of criteria for road placement, it is not clear what specific measures ERA uses to operationalize them. For instance, it is not clear how exactly economic potentials of different geographic locations are assessed or how regional inequality is evaluated. There is lack of clarity also about the process and criteria by which regional states prioritize their road projects for submission to ERA. From our discussion with ERA, it seems that the above mentioned criteria serve as broad guidelines rather than strict rules for road placement. 
Appendix B:

Table B1: Expected Improvement in Speed of Travel

\begin{tabular}{|l|c|c|}
\hline \multirow{2}{*}{$\begin{array}{l}\text { Pavement Type and } \\
\text { Condition }\end{array}$} & \multicolumn{2}{|c|}{$\begin{array}{l}\text { Average Travel Speed } \\
\text { Refore }\end{array}$} \\
\hline Asphalt Roads & $50 \mathrm{~km} / \mathrm{hr}$ & $\begin{array}{l}\text { After } \\
\text { Rehabilitation/upgrading }\end{array}$ \\
\hline Federal Gravel Road & $35 \mathrm{~km} / \mathrm{hr}$ & $70 \mathrm{~km} / \mathrm{hr}$ \\
\hline Regional Gravel Road & $25 \mathrm{~km} / \mathrm{hr}$ & $45 \mathrm{~km} / \mathrm{hr}$ \\
\hline Earth Surfaced Roads & $20 \mathrm{~km} / \mathrm{hr}$ & $35 \mathrm{~km} / \mathrm{hr}$ \\
\hline $\begin{array}{l}\text { Federal Gravel or regional } \\
\text { rural roads to Asphalt Roads }\end{array}$ & $25 \mathrm{~km} / \mathrm{hr}$ to $35 \mathrm{~km} / \mathrm{hr}$ & $35 \mathrm{~km} / \mathrm{hr}$ \\
\hline
\end{tabular}

Source: ERA

Table B2: Regional Capitals and other Urban Centers as Destination for O-D matrix

\begin{tabular}{|r|l|r|r|}
\hline ID & NAME & POINT X & \multicolumn{1}{c|}{ POINT_Y } \\
\hline 1 & Addis Abeba & 472656.04 & 998453.60 \\
\hline 2 & Arba Minch & 338197.89 & 664536.16 \\
\hline 3 & Asosa & 10524.93 & 1115450.18 \\
\hline 4 & Awasa & 441088.20 & 779102.38 \\
\hline 5 & Bahir Dar & 324514.77 & 1281398.44 \\
\hline 6 & Dessie & 568955.98 & 1229367.46 \\
\hline 7 & Dire Dawa & 814860.19 & 1063118.29 \\
\hline 8 & Gambela & 12264.77 & 913864.40 \\
\hline 9 & Harer & 842893.99 & 1030414.93 \\
\hline 10 & Jigjiga & 917315.59 & 1035495.53 \\
\hline 11 & Jima & 260937.87 & 848508.63 \\
\hline 12 & Mekele & 551884.95 & 1492540.45 \\
\hline 13 & Nazret & 528918.44 & 943849.55 \\
\hline 14 & Nekemte & 230291.32 & 1005545.02 \\
\hline 15 & Semera & 717990.30 & 1300962.68 \\
\hline
\end{tabular}

